\title{
Effects of sizing and yarn structural properties on the physical properties of combed and carded cotton ring yarns
}

DOI: $10.35530 / I T .069 .02 .1329$

\begin{abstract}
REZUMAT - ABSTRACT
Efectul încleierii și proprietăților structurale ale firelor asupra proprietăților fizice ale firelor din bumbac cardate și pieptănate filate cu inele
\end{abstract}

Firele de urzeală, pregătite sub formă de suluri de urzeală, sunt expuse diferitelor forțe ale mașinii de țesut. Firele de urzeală sunt curbate pe traversa de tensionare, supuse frecării în lamele și cocleți. Acestea sunt, de asemenea, expuse la frecarea și impactul spatei și, prin urmare, abraziunii. Firele sunt încleiate pentru a crește rezistența lor la aceste efecte. Agenții de încleiere, prin procesul de încleiere, permit firelor de urzeală să fie țesute. Pe de altă parte, finețea firelor și tipul de fir (pieptănat sau cardat) sunt proprietățile structurale semnificative care determină proprietățile fizice ale firelor.

Principalul obiectiv al acestui studiu este de a investiga efectele parametrilor structurali (finețea firului și tipul de fir) și a încleierii asupra proprietăților fizice (rezistența la rupere, alungirea la rupere, pilozitatea, coeficientul de frecare) ale firelor de bumbac 100\% cardate și pieptănate filate cu inele, încleiate cu patru agenți de încleiere diferiți, care nu au fost studiați în referințe. Se observă că procesul de încleiere determină o scădere a pilozității cu până la $99 \%$ și a coeficienților de frecare ai firelor cardate și pieptănate, în timp ce crește rezistența la rupere a firelor cardate și pieptănate. De asemenea, firele pieptănate au avut proprietăți mai bune de rezistență la rupere și la frecare decât firele cardate.

Cuvinte-cheie: fir cardat, fir pieptănat, fir filat cu inele, încleiere, rezistență la rupere, alungire la rupere, pilozitate, coeficient de frecare

\section{Effects of sizing and yarn structural properties on the physical properties of combed and carded cotton ring yarns}

Warp yarns, prepared as warp beam, are exposed to various forces at weaving loom. Warp yarns are bended on the back rest, subjected to friction from drop wires and healds. They are also exposed to friction and impact at reed and thereby abraded. Yarns are sized in order to increase their resistance to these effects. Sizing agents ensure that warp yarns can be weaved with sizing process. On the other hand, yarn count and yarn type (combed or carded yarn) are the significant yarn structural properties that determine and so affect the physical properties of yarn. The main reason and objective this study is to investigate the effects of yarn structural parameters (yarn count and yarn type) and sizing on the physical properties (breaking strength, elongation at break, hairiness, friction coefficient) of $100 \%$ cotton carded and combed ring yarns, sized with four different sizing agents, which were not studied in the references. It is observed that sizing process cause to decrease in the hairiness up to $99 \%$ and in friction coefficients of combed and carded yarns whereas to increase in the breaking strengths of combed and carded yarns. And also, the combed yarns had better tensile and frictional properties than carded yarns.

Keywords: carded yarn, combed yarn, ring yarn, sizing, breaking strength, elongation at break, hairiness, coefficient of friction

\section{INTRODUCTION}

The weaving process is based on various factors and on interaction of these factors, including yarn structural parameters, the sizing operation and the sizing agents. Yarn has a complex structure and is defined by many physical properties. It has been considered that the tensile properties of the yarn, which are strength and elongation, are always the prime factors which affect the performance of warp yarns during weaving and weaving preparation. Nevertheless, in recent years it has been realized that the hairiness and friction properties of yarns have equal influence on the performance of the loom and warping machine. The warp yarns may break during the process of weaving and warping due to the complicated mechanical actions consisting of cyclic or noncyclical extension, friction and bending. In order to prevent warp yarns from excessive breakage during weaving and warping, the threads should be sized to be gained better friction properties and to be improved their strength. Sizing is the important weaving preparation operation in terms of decreasing the number of breaks both in weaving and warping processes of cotton yarns. So it increases efficiency of loom and warping machine and also woven fabric quality. Therefore researchers investigated the effects of sizing on yarn physical properties: Schwarz, Kovacevic and Dimitrovski analysed areas of elastic, viscoelastic and plastic deformations of ring and rotor-spun yarns before and after sizing with a PVA sizing agent, using the same recipe, but with two different size concentrations, $7.5 \%$ and $5.0 \%$ [1]. By sizing, they achieved major improvements in mechanical properties of ring-spun yarns, contrary to the minor 
improvements in mechanical properties of rotor-spun yarns, due to their structures.

Behera, B.K., Pakhira, A. applied various size materials (polyvinyl alcohol, polyester resin, polyacrylamide) to both flat (with linear density per filament of $1.04,2.08$ and 4.41 den, respectively) and textured (0.50, 1.41 and 2.22 den per filament, respectively) zero-twisted PET multifilament yams [2]. They observed that breaking strength of yarns increased with sizing whereas breaking extension (\%) of yarns decreased with sizing. While difference between yarns sized with polyester resin and unseized yams were significant (at $1 \%$ level) for all yarns, difference between yarns sized with polyvinyl alcohol and unseized yams were significant for 4.41 den flat, 1.41 and 2.22 den textured yarns.

Maatoug, S., Ladhari, N. and Sakli, F. investigated the physical properties of $\mathrm{Nm} 12.2$ cotton warp yarns sized at high pressure squeezing with maize starch, polyvinyl alcohol and carboxymethyl cellulose [3]. They observed that the breaking strengths of all sized yarns increased when compared with unsized yarns, while their breaking extensions were reduced. And also, hairiness decreased with sizing.

Behera, B.K. and Joshi, V.K. evaluated relative weaving potential of Dref yarns, with core of polyester filament and cotton sheath and with core of cotton yarn and cotton sheath, which were sized modified maize starch and with acrylic size [4]. They observed that increasing size add-on increased the weaving performance of Dref yarns and the optimum size add-on was approximately $15 \%$.

Jaouachi, B., Ben Hassen, M. and Saklı, F. sized the wet pneumatic-spliced denim yarns according to two different recipes [5]. They found that sizing encouraged the breaking strength of spliced yarns. In other study, Jaouachi, B., Ben Hassen, M. and Saklı, F. compared the mechanical behaviours (breaking strength, elongation at break) of both parent and wet pneumatic spliced cotton denim yarns before and after sizing by natural and synthetic sizes [6]. They found that the synthetic size gave better performance to wet spliced cotton yarns.

Carded cotton yarn, that is carded but not combed, contains a wider range of fibre lengths as a result of this, it is not as uniform and as strong as combed yarns. And also, combed cotton yarn in which the fibres are straightened and parallel to each other, have smooth surfaces [7].

Furthermore, no studies have been found so far on the effect of different sizing recipes on the mechanical properties (breaking strength, elongation at break, hairiness, friction coefficient) of carded and combed cotton ring yarns with various thicknesses. This study is an attempt to fill this gap and endeavours to add a little more knowledge to what is already known in this domain.

\section{EXPERIMENTAL WORK}

\section{Materials and Method}

\section{Materials}

\section{- Yarns}

$100 \%$ cotton carded and combed single yarns, whose specifications are given in table 1 , were used in the experiments. While the latter in fabric codes represent the yarn type and yarn count together, the number represents the sizing agents.

Table 1

\begin{tabular}{|c|c|c|c|}
\hline \multicolumn{4}{|c|}{ THE SPECIFICATIONS OF YARNS } \\
\hline $\begin{array}{c}\text { Yarn } \\
\text { code }\end{array}$ & Raw material & Yarn type & $\begin{array}{c}\text { Yarn count } \\
\text { (Ne) }\end{array}$ \\
\hline A0 & $100 \%$ Cotton & Ring (Combed) & $\mathrm{Ne} 20 / 1$ \\
\hline B0 & $100 \%$ Cotton & Ring (Combed) & $\mathrm{Ne} 30 / 1$ \\
\hline C0 & $100 \%$ Cotton & Ring (Combed) & $\mathrm{Ne} 40 / 1$ \\
\hline D0 & $100 \%$ Cotton & Ring (Carded) & $\mathrm{Ne} 16 / 1$ \\
\hline E0 & $100 \%$ Cotton & Ring (Carded) & $\mathrm{Ne} \mathrm{20/1}$ \\
\hline F0 & $100 \%$ Cotton & Ring (Carded) & $\mathrm{Ne} \mathrm{30/1}$ \\
\hline
\end{tabular}

\section{- Size materials}

The following size materials and agents, provided by industry, were used: i) Emsize E6 (potato starch); ii) Ensize TX11 (synthetic polyvinyl alcohol); iii) Emsize CMS60 (carboxyl methyl cellulose); iv) Ensize TX79 (natural polyvinyl alcohol); v) Wachs (softener).

The friction between the reed and warp yarns are high, therefore slippery sizing film is required. In order to increase the slipperiness of sizing film, watches were used as softener.

\section{Methods}

\section{- Yarn sizing}

The sizing process was carried out in weaving workshop of in-house by $\mathrm{CCl}$ laboratory sizing machine (SS560, Taiwan). Sizing consisted of three steps; yarns were immersed in sizing liquor in the first step. In the second, a pair of squeezing rollers, enabling the regulation of the squeezing pressure, sent away too much sizing agent. In the last step, yarns were dried in a heating chamber.

Four different sizing liquors were prepared in Finishing Laboratory of in-house with a size percentage of $10 \%, 5 \%, 10 \%$ and $5 \%$, using sizing recipes containing Emsize E6, Ensize TX11, Emsize CMS60 and Ensize TX79, respectively. Wachs, a percentage of $2 \%$, was also added to all size recipes as softener. Size liquors were heated up to $90^{\circ} \mathrm{C}$ and scoured at $90^{\circ} \mathrm{C}$ during 20 minute. While temperature of sizing chamber was set $90^{\circ} \mathrm{C}$, temperature of heating chamber was set $86^{\circ} \mathrm{C}$ during the sizing process. All conditions mentioned did not change during the process, so it can be claimed that the conditions for all the yarns tested were the same.

\section{- Test methods and testing instruments}

Firstly, sized and unsized yarns were conditioned at standard atmosphere conditions during 24 hours. In 


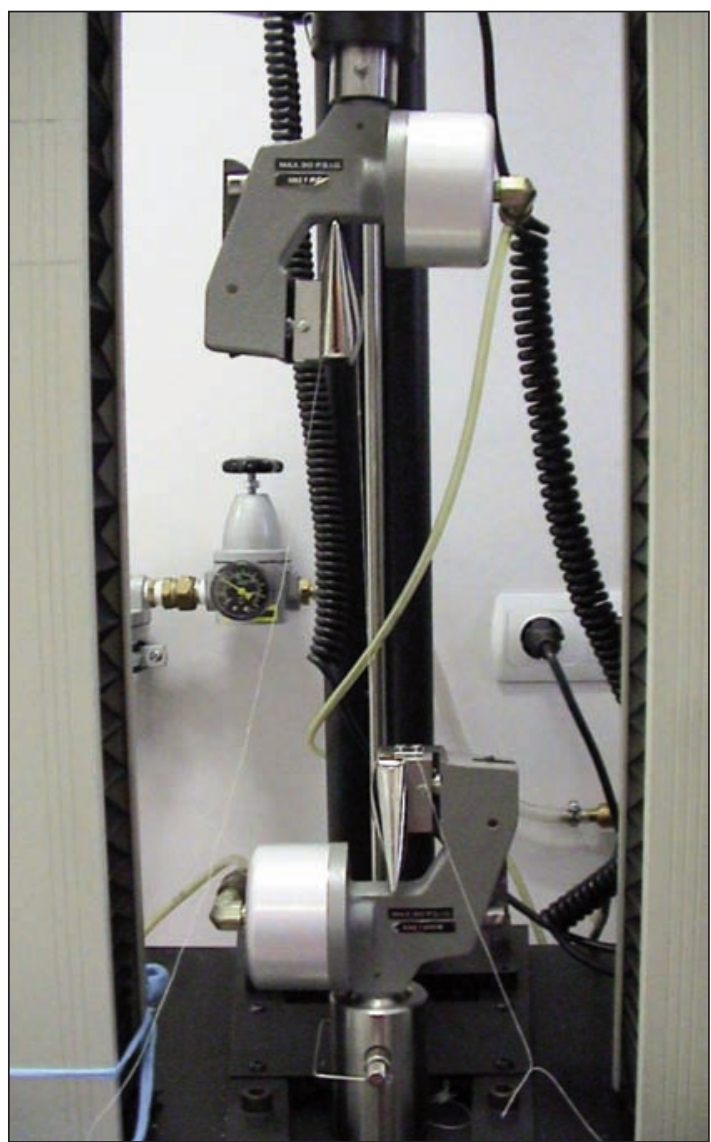

Fig. 1. Multipurpose Strength Tester

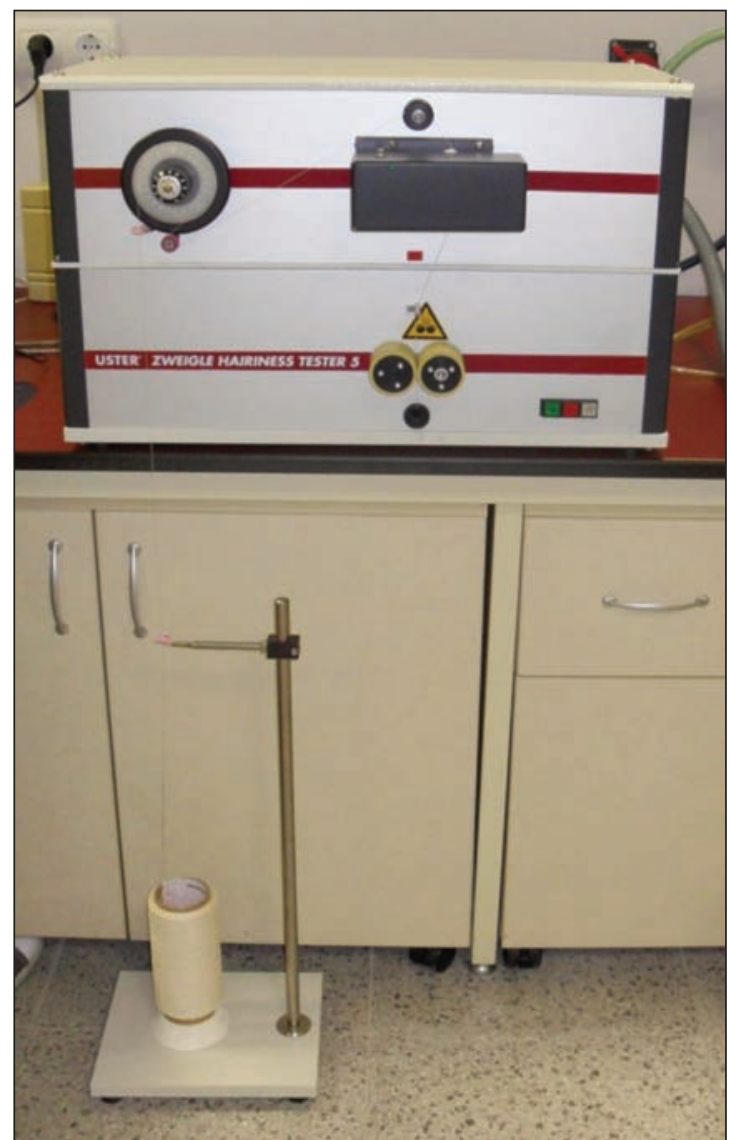

Fig. 2. Hairiness Tester order to repeat the tests, all tests were performed also at standard atmosphere conditions in Physical Testing Laboratory of in-house.

Unseized yarns' twists, given in table 1, were determined by electronic twist measurement device according to EN ISO 2061 [8]. Measurements were performed in accordance with the Open-Close method, because yarns are single yarns. Measurement length was $25 \mathrm{~cm}$. And then twist per meter was calculated. Breaking forces and elongation at breaks of yarns were measured by INSTRON Multipurpose Strength Tester (4411, USA), shown in figure 1, according to EN ISO 2062 at $100 \mathrm{~mm} / \mathrm{min}$ [9]. Measurement length was $200 \mathrm{~mm}$. Load cell, whose capacity is $500 \mathrm{~N}$, was used.

Hairiness of yarns was determined by Uster Zweigle Hairiness Tester (5, Switzerland), shown in figure 2, according to ASTM D5647-07 at $50 \mathrm{~m} / \mathrm{min}$. The input tension was $5 \mathrm{cN}$ [10]. Measurement length was $100 \mathrm{~m}$. Friction tests were also performed by Lawson Hemphill Dynamic Friction Tester (CTT, USA) according to ASTM D3108 at $100 \mathrm{~mm} / \mathrm{min}$ [11]. Co-efficient of friction between yarns and solid material, shown in figure 3 , were determined. The input tension was $15 \mathrm{cN}$.

\section{- Statistical evaluation}

Breaking test results were evaluated statistically by ANOVA according the General Linear Model with SPSS 15.0 software package. In order to analyse the effect of sizing and yarn count, multivariate analysis

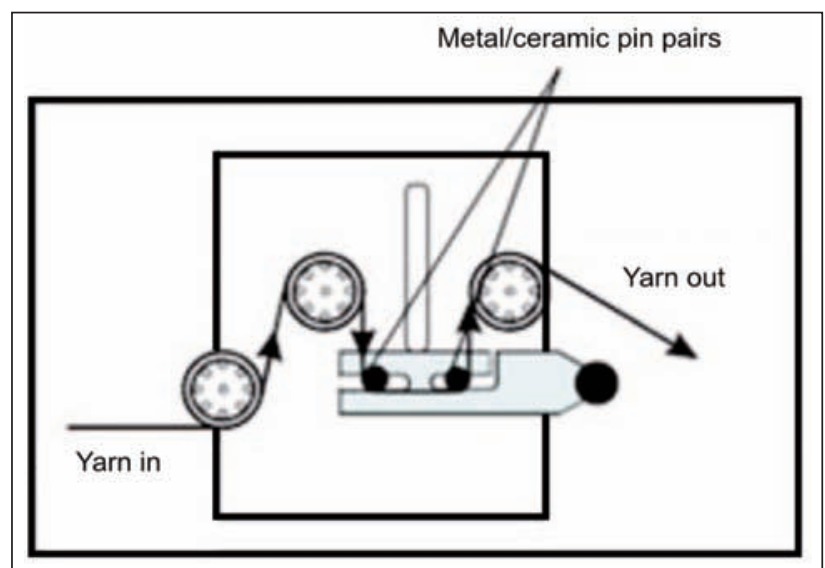

Fig. 3. Yarn to solid material friction in Dynamic Friction Tester [12]

was made for the two groups of yarns: one including combed yarns and the other including carded yarns. Significance degrees $(p)$, which were obtained from ANOVA, were compared with significance level $(\alpha)$ of 0.05 . The effect, whose significance degree was lower than 0.05 , was interpreted as statistically important.

Besides, the effect of yarn type on breaking force and elongation at break of yarns was evaluated by $t$ tests for combed and carded yarns, whose counts were the same. $t$ tests were done by MATLAB 6.5 with significance level $(\alpha)$ of 0.05 also. Hypothesis of $h_{0}$ was defined that averages were equal. If $h$, the calculated 
value, was equal to $1, h_{0}$ would be ignored, namely; the difference between the breaking test results is statistically important.

\section{RESULTS AND DISCUSSION}

Average values of all tests results are given in table 2 . The hairiness tests of yarns, coded as D1, F1, A3, B3, E3, F3, F4, could not be performed, because bending rigidity of these yarns increased with sizing.

\section{Yarn twist test results}

Yarn twists are shown in figure 4. From the figure, it is seen that yarn twist increases expectedly when the yarn count increases, namely the yarn becomes thinner, for $\mathrm{AO}, \mathrm{BO}$ and $\mathrm{C} 0$, which were combed yarns, and for DO, E0, and F0, which were carded yarns. While the twist of $A 0$ is almost equal to the twist of E0, the twist of BO were almost equal to the twist of F0, which were the combed and carded yarns with the same count.

Table 2

\begin{tabular}{|c|c|c|c|c|c|}
\multicolumn{6}{|c|}{ TENSILE, HAIRINESS AND FRICTION PROPERTIES } \\
OF YARNS \\
\hline $\begin{array}{c}\text { Yarn } \\
\text { code }\end{array}$ & $\begin{array}{c}\text { Twist } \\
\text { (T/m) }\end{array}$ & $\begin{array}{c}\text { Breaking } \\
\text { force } \\
\text { (gf) }\end{array}$ & $\begin{array}{c}\text { Elongation } \\
\text { at break } \\
\text { (\%) }\end{array}$ & $\begin{array}{c}\text { Hairiness } \\
\text { (S3) }\end{array}$ & $\begin{array}{c}\text { Coefficient } \\
\text { of friction } \\
(\boldsymbol{\mu})\end{array}$ \\
\hline A0 & 668 & 491,0 & 9,76 & 3141 & 0,23 \\
\hline B0 & 857 & 362,4 & 8,88 & 2104 & 0,22 \\
\hline C0 & 1008 & 187,0 & 6,16 & 1880 & 0,21 \\
\hline D0 & 631 & 600,4 & 10,85 & 4317 & 0,25 \\
\hline E0 & 682 & 473,0 & 9,17 & 3576 & 0,24 \\
\hline F0 & 831 & 322,8 & 8,50 & 2470 & 0,23 \\
\hline A1 & - & 609,9 & 7,09 & 31 & 0,22 \\
\hline B1 & - & 397,6 & 7,76 & 14 & 0,21 \\
\hline C1 & - & 266,4 & 5,45 & 11 & 0,20 \\
\hline D1 & - & 706,6 & 8,89 & - & 0,24 \\
\hline E1 & - & 611,4 & 7,24 & 40 & 0,23 \\
\hline F1 & - & 334,6 & 6,08 & - & 0,22 \\
\hline A2 & - & 589,1 & 8,71 & 12 & 0,18 \\
\hline B2 & - & 393,3 & 8,31 & 8 & 0,18 \\
\hline C2 & - & 265,6 & 5,56 & 3 & 0,17 \\
\hline D2 & - & 749,0 & 9,38 & 16 & 0,20 \\
\hline E2 & - & 612,5 & 8,54 & 13 & 0,19 \\
\hline F2 & - & 361,1 & 7,41 & 5 & 0,18 \\
\hline A3 & - & 620,8 & 8,95 & - & 0,20 \\
\hline B3 & - & 392,3 & 8,04 & - & 0,19 \\
\hline C3 & - & 300,1 & 5,68 & 23 & 0,18 \\
\hline D3 & - & 682,9 & 8,61 & 69 & 0,21 \\
\hline E3 & - & 604,3 & 8,31 & - & 0,20 \\
\hline F3 & - & 371,1 & 7,74 & - & 0,20 \\
\hline A4 & - & 604,0 & 7,69 & 48 & 0,21 \\
\hline B4 & - & 364,1 & 8,20 & 27 & 0,20 \\
\hline C4 & - & 272,2 & 5,48 & 20 & 0,19 \\
\hline D4 & - & 675,2 & 8,49 & 78 & 0,23 \\
\hline E4 & - & 567,3 & 8,28 & 66 & 0,22 \\
\hline F4 & - & 337,8 & 7,31 & - & 0,21 \\
\hline
\end{tabular}

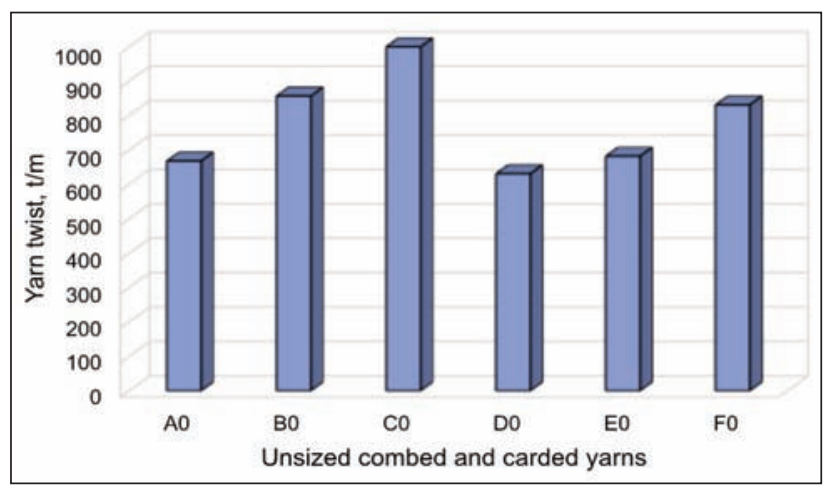

Fig. 4. Yarn twist

\section{Breaking strength test results}

Breaking force and elongation at break values of yarns are shown in figure 5 and figure 6 , respectively. When we look at the effect of yarn structural properties on yarn tensile properties, it is observed that the breaking force of $\mathrm{A} 0$ was $26.19 \%$ higher than that of B0, whereas the breaking force of B0 was $48.4 \%$ higher than that of $\mathrm{C} 0$. While the breaking force of D0 was $21.22 \%$ higher than that of E0, the breaking force of E0 was $31.75 \%$ higher than that of FO. Similarly, A0 had $9.02 \%$ higher elongation at break values than $\mathrm{B} 0$, whereas the $\mathrm{B} 0$ had $30.63 \%$ higher elongation at break values than $\mathrm{CO}$. While DO had $15.48 \%$ higher elongation at break values than E0, E0 had $7.31 \%$ higher elongation at break that of F0. This is because of the fact that more fibres in cross

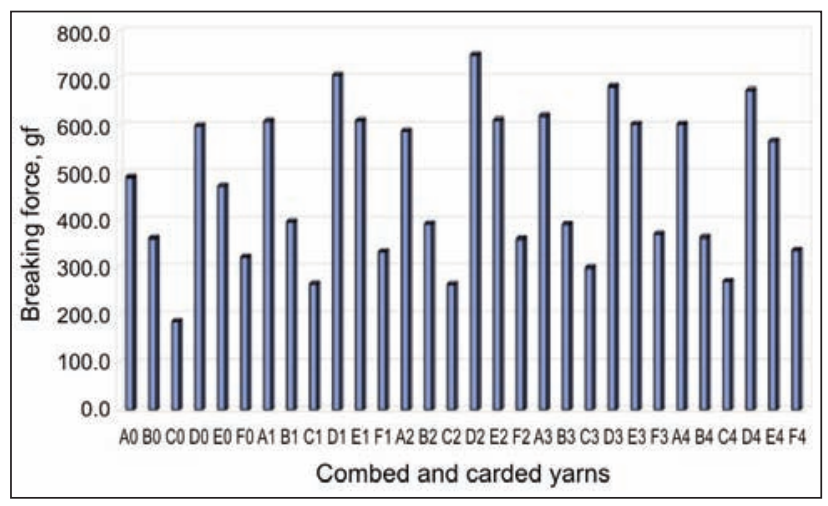

Fig. 5. Breaking force of yarns

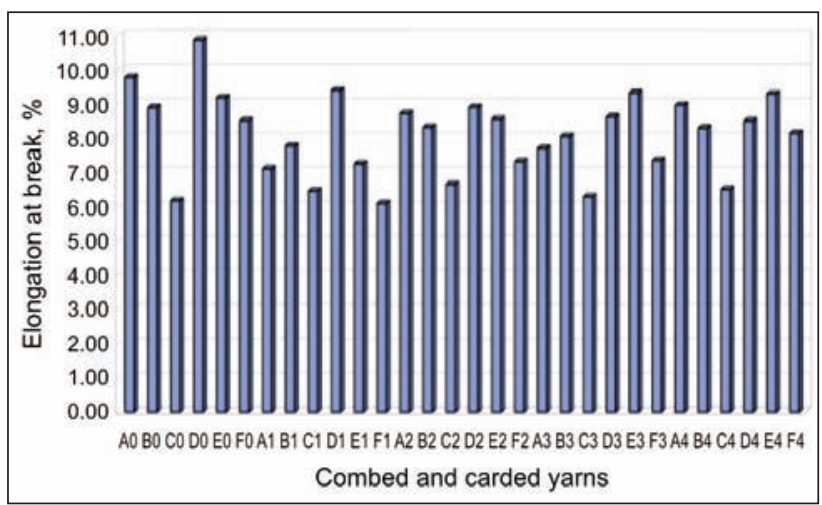

Fig. 6. Elongation at break of yarns 
section of thicker yarns have more breaking strength and cause thicker yarns to elongate more.

The breaking force of $\mathrm{A} 0$, combed yarn, was $3.67 \%$ higher than that of E0, carded yarn, and also the breaking force of $\mathrm{B} 0$, combed yarn, was $10.93 \%$ higher than that of F0, carded yarn. In like manner, $\mathrm{A} 0$ had $6.05 \%$ higher elongation at break values than E0. Moreover, BO had $4.28 \%$ higher elongation at break values than F0. This is due to the fact that, combed yarns are spun from longer staple fibres, which have uniform length distribution. Therefore combed yarns had more twists and resisted more to the forces along their axis during the breaking tests. When we look at the effect of sizing on yarn tensile properties, it is seen that all size agents, used in experimental, raised the breaking force of combed and carded yarns: the highest increments is observed between A0-A3, B0-B3, E0-E3, sized with carboxyl methyl cellulose and C0-C2, D0-D2, E0-E2, sized with synthetic polyvinyl alcohol.

On the other hand, all sizing agents reduced the elongation at break values of sample yarns. Carboxyl methyl cellulose reduced the elongation at break of $\mathrm{AO}, \mathrm{CO}$ and F0 minimum. And also synthetic polyvinyl alcohol diminishes the elongation at break of B0, D0 and EO minimum.

\section{Hairiness test results}

Hairiness of yarns is shown in figure 7. From the figure, it is observed that while the hairiness of $A 0$ was $33.01 \%$ higher than that of $\mathrm{B} 0$, the hairiness of $\mathrm{B} 0$ was $10.65 \%$ higher than that of C0. Similarly, D0 had $17.16 \%$ higher hairiness values than $\mathrm{E} 0$, whereas $\mathrm{E} 0$ had $30.93 \%$ higher hairiness values than F0. This is because of the fact that, thinner yarns have more twists and also less number of fibres in their cross sections. For this reasons, they have less hairiness. It is seen that the hairiness of $A 0$ was $12.16 \%$ lower than that of E0, whereas the hairiness of B0 was $14.82 \%$ lower than that of F0. Because longer and collimated staple fibres, in the structure of combed yarns, are twisted more uniformly. This will decrease the unevenness of yarn, twist and yarn hairiness.

It is observed that the effects of sizing agents on hairiness were almost the same. The hairiness of yarns reduced between $98.15 \%$ and $99.84 \%$ after sizing. This is due to the fact that size agents stick the surface fibres to the yarn surface.

\section{Friction test results}

Friction coefficients of yarns are shown in figure 8 . From the figure, it is seen that the friction coefficient of $\mathrm{A} 0$ was $4.35 \%$ higher than that of $\mathrm{B} 0$, whereas the friction coefficient of B0 was $4.55 \%$ higher than that of $\mathrm{C} 0$. While the D0 had $4 \%$ higher friction coefficient values than E0, E0 had $4.17 \%$ higher friction coefficient values than F0. This probably results from the fact that the thinner yarns have less number of surface fibres. This reduces the friction between fibres and metal/ceramic pin pairs of Friction Tester.

While the friction coefficient of $\mathrm{AO}$ was also $4.17 \%$ lower than that of E0, the friction coefficient of B0 was also $4.35 \%$ lower than that of F0. This is because of the fact that combed yarns are constituted by uniformly

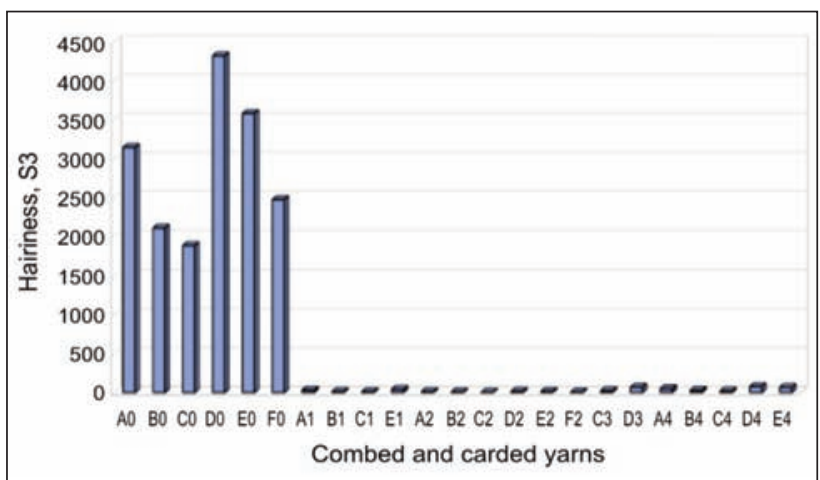

Fig. 7. Hairiness of yarns

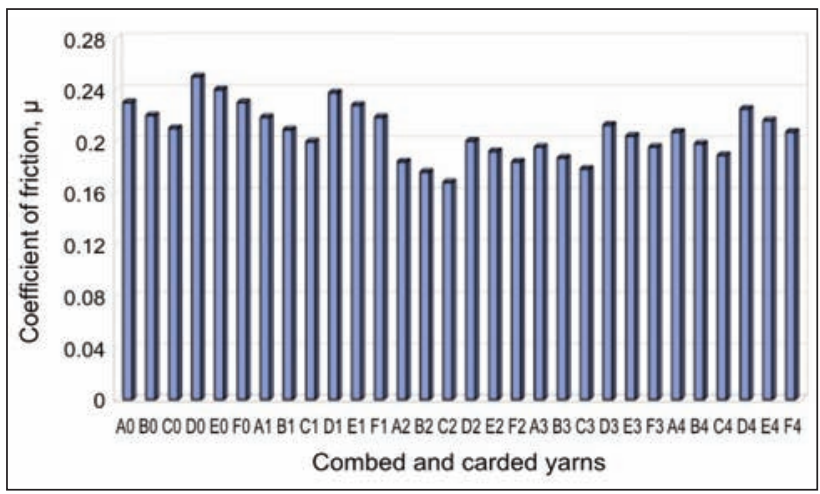

Fig. 8. Friction coefficient of yarns

twisted fibres and thereby have more smother surface than carded yarns.

The friction coefficient of all yarn samples declined with sizing. Because, sizing agents stick the fibres to the yarn surface. So, unevenness and roughness of yarn therefore decreases. The biggest diminish is observed for the A2, B2, C2, D2, E2 and F2, sized with synthetic polyvinyl alcohol, approximately $20 \%$, whereas the second reduce is seen for the A3, B3, C3, D3, E3 and F3, sized with carboxyl methyl cellulose, approximately $15 \%$.

\section{Statistical results}

From the results of ANOVA, made for combed and carded yarns separately, it can be concluded that the effect of yarn count and sizing on the breaking strength and the elongation at break of both combed and carded yarns are statistically important at the significance level of 0.05 , getting the $p$-value of $(0.000)$ for all analysis.

From the results of $t$ tests, performed for breaking strength of combed and carded yarns, sized different sizing agents, with the same count separately, it can be deduced that the differences of breaking strength averages (B0 and $\mathrm{F} 0, \mathrm{~B} 1$ and $\mathrm{F} 1, \mathrm{~B} 2$ and $\mathrm{F} 2, \mathrm{~B} 3$ and F3, B4 and F4, A4 and E4) are statistically important at the significance level of 0.05 .

From the results of $t$ tests, performed for elongation at break of combed and carded yarns, sized different sizing agents, with the same count separately, it can be concluded that yarn type affected the elongation at break of yarns sized with different sizing agents statistically $(\alpha=0.05)$. 


\section{CONCLUSIONS}

Statistical and experimental studies were conducted within the scope of this study to determine the effects of sizing and yarn count, yarn type, which are yarn important structural parameters, on the breaking strength, elongation at break, hairiness and coefficient of friction. It was found that the mentioned parameters affected the physical properties of $100 \%$ cotton carded and combed single ring yarns:

It is observed for both combed and carded yarns that thinner yarns were twisted more with the decreasing number of fibres in cross sections of thinner yarns. The combed and carded yarns, with the same count, had almost the same twist.

The breaking force and the elongation at break of combed and carded yarns increased with the decrease in yarn count expectedly, because of the more fibres in cross section of thicker yarns.

Combed yarns, which were spun from longer staple fibres, whose lengths were uniformly distributed, showed better performance during tensile tests. So they had better breaking strength and elongation at break values than carded yarns.

It is observed that hairiness of thinner yarns, which had less number of fibres in their cross sections and more twists, were lower than those of thicker yarns. Hairiness of combed yarns, which were constituted from longer staple fibres and also parallel to each other, was better than those of carded yarns with the same count.
It is seen that friction coefficients of thinner yarns, that had more twist and less number of fibres in their surfaces and thereby had more smother surfaces, were lower than those of thicker yarns.

Furthermore, friction coefficients of combed yarns, which were comprised of uniformly twisted fibres and thereby had smother surfaces, were lower than those of carded yarns with the same count.

While the braking forces of all yarns increased with all sizing agents used in this study, elongation at break of yarns decreased with sizing agents.

It is observed that the hairiness of yarns sized with all sizing agents used in this research decreased, because of the fact that sizing agents fix fibres to the yarn surfaces. The hairiness tests of some yarns could not be performed, because of increment in bending rigidity of these yarns with sizing.

The friction coefficients of yarns, determined by means of friction tester, decreased with sizing.

Synthetic polyvinyl alcohol and carboxyl methyl cellulose, sizing agents, have the best effects on the frictional and tensile properties of $100 \%$ cotton ring yarns. Consequently, the $100 \%$ cotton combed ring yarns show better performance than in tensile tests before and after sizing. It can be concluded from the results that sizing treatment improves the tensile as well as the frictional properties of $100 \%$ cotton carded and combed ring yarns. As a result, weaving performance of sized cotton ring yarns were enhanced. The increments in the performance of sized yarns results from not onlyincrease in the breaking strength but also diminish in friction coefficients of sized yarns.

\section{BIBLIOGRAPHY}

[1] Schwarz, I.G., Kovacevic, S., Dimitrovski, K. Analysis of changes in mechanical and deformation properties of yarn by sizing. In: Textile Research Journal, 2011, vol. 81, issue 5, p. 545.

[2] Behera, B.K., Pakhira, A. Evaluation of the weavability of polyester-fibre multifilament sized yarn. In: Journal of the Textile Institute, 1998, vol. 89, issue 3, p. 522.

[3] Maatoug, S., Ladhari, N., Sakli, F. Evaluation of the weavability of sized cotton warps. In: AUTEX Research Journal, 2007, vol. 8, issue 4, p. 239.

[4] Behera, B.K., Joshi, V.K. Effect of sizing on weavability of Dref yarns. In: AUTEX Research Journal, 2006, vol. 6, issue 3 , p. 142.

[5] Jaouachi, B., Ben Hassen, M., Saklı, F. Strength of wet spliced denim yarns after sizing using a central composite design. In: AUTEX Research Journal, 2009, vol. 7, issue 3, p. 159.

[6] Jaouachi, B., Ben Hassen, M., Saklı, F. Optimisation of the behaviour of sized wet spliced yarns. In: AUTEX Research Journal, 2009, vol. 9, issue 1, p. 1.

[7] Mahadevan, M. G. Textile spinning, weaving and designing. In: Abhishek Publications, 2009, pp. 16-17.

[8] ISO EN 2061. Textiles - Determination of twist in yarns - Direct counting method, 2010.

[9] EN ISO 2062. Textiles - Yarns Form Packages - Determination of Single-End Breaking Force and Elongation at Break, 1995.

[10] ASTM D5647-07. Standard Guide for Measuring Hairiness of Yarns by the Photo-Electric Apparatus, 2012.

[11] ASTM D 3108. Standard Test Method for Coefficient of Friction, Yarn to Solid Material, 2013.

[12] Kilic, G.B., Sülar, V. Frictional properties of cotton-tencel yarns spun in different spinning systems. In: Textile Research Journal, 2012, vol. 82, issue 8, p. 755.

Authors:

HAKAN ÖZDEMIR

DokuzEylül University, Faculty of Engineering, Department of Textile Engineering

Buca-35397, İzmir-TURKEY

e-mail: h.ozdemir@deu.edu.tr 